special opportunities for study or research to suitably qualified British subjects of either sex "intending to devote themselves to the advancement by teaching or research of curative or preventive treatment of tuberculosis in all or any of its forms". The Fellowships will, as a rule, be awarded to candidates who wish to make their studies or inquiries elsewhere than in the United Kingdom. They provide for the payment of a maintenance allowance at the rate of $£ 650$ a year for a single Fellow and $£ 900$ for a married Fellow; in addition, an allowance will be made for travelling and otber approved expenses. Further particulars can be obtained from the Secretary, Medical Research Council, 38 Old Queen Street, Westminster, S.W.1, with whom applications must be lodged not later than March 15.

\section{Oil and Colour Chemists' Association}

The 1955 Conference of the Oil and Colour Chemists' Association will be held at Llandudno during June 7-11. Most members will be accommodated at the Grand Hotel, where the technical sessions, under the general title "Film Structure and Adhesion", will be held.

The seventh Technical Exhibition of the Associa. tion will be held during March 15-17 at the Royal Horticultural Society's Old Hall, Vincent Square, London, S.W.1. Further information can be obtained from the General Secretary, Oil and Colour Chemists' Association, Memorial Hall, Farringdon Street, London, E.C.4.

The British Instrument Industries' Exhibition, 1955

THE third British Instrument Industries' Exhibition will be held at Earls Court, London, during June 28-July 9. Concurrently with this Exhibition, there is the tenth International Printing Machinery and Allied Trades' Exhibition at Olympia, and in view of the rapidly growing importance of instrumentation to the printing industry, visitors to this will have the advantage of studying both modern printing machinery and the appropriate field of instrumentation, including temperature control.

\section{University of Birmingham}

DR. T. L. IBBS has been awarded the personal title of professor and has been appointed to administer the Department of Physics from January 1, 1955, to September 30, 1956, in order to release Prof. P. B. Moon for duties in connexion with the research programme of the department.

A grant of $£ 2,000$ a year for three years has been accepted from the Aero Research Company for fundamental work on fluorine compounds in the Department of Chemistry.

The title of University Research Fellow has been conferred upon Dr. C. A. Diaz Floris during the tenure of his present post in the Department of Chemical Engineering.

\section{Announcements}

WE regret to announce the death on January 30 of Sir Edward Mellanby, lately secretary of the Medical Research Council, aged seventy.

Dr. R. A. Lyttreton, of St. John's College, Cambridge, has been awarded the Hopkins Prize of the Cambridge Philosophical Society for his work on comets and on the stability of rotating liquid masses. The Prize, which is of value $£ 90$, has been awarded every three years since 1867 for work in mathe- matical-physical or related fields. The last recipient was the late Sir John Lennard-Jones.

Str Charles Dodds, Courtauld professor of biochemistry in the University of London and director of the Courtauld Institute of Biochemistry at the Middlesex Hospital, has been appointed a member of the Advisory Council for Scientific and Industrial Research, to fill the vacancy caused by the retirement of the late Sir Wallace Akers in September 1954.

Prof. S. Devons, professor of physics in the Imperial College of Science and Technology, London, since 1950 (see Nature, 164, 1033; 1949), has been appointed Langworthy professor of physics and director of the Physical Laboratories, University of Manchester. He thus succeeds Prof. P. M. S. Blackett, who accepted a chair in the Imperial College in 1953.

Dr. H. M. STANLEY has been appointed controller of research and development of the Distillers Co., Ltd., in succession to Dr. F. Roffey, who remains technical director of the Company and has taken on the additional duties of personnel director of the Company's Industrial Group.

Trinity College, Cambridge, is offering Entrance Exhibitions to students of universities in the British Commonwealth. These are confined to those who propose reading for a B.A. (honours), LL.B. degree or a diploma. The awards are not intended for research students. Each Exhibition is of the titular value of $£ 40$ a year. The College is also offering a Research Studentship. The value will depend on the student's income from other sources; if there are no other emoluments, the Studentship will be $£ 425$ a year. Further information can be obtained from the Senior Tutor, Trinity College, Cambridge.

AN International Ore-dressing Congress will be held under the auspices of the Gesellschaft Deutscher Metallhütten- und Bergleute in Goslar (Harz) during May 8-11. Further information can be obtained from W. Koch, Gesellschaft Deutscher Metallhüttenund Bergleute, Clausthal-Zellerfeld 1 (Germany), Postfach 51.

AN International Congress on Materials for Aircraft and Guided Missiles will be held in Paris under the auspices of the Association pour l'Encouragement à la Recherche Aéronautique during March 28-April 1. Further information can be obtained from M.P. Lefranc, délégué technique, Association pour l'Encouragement à la Recherche Aéronautique, 1 rue de Courty, Paris 7.

This year is the fortieth anniversary of the publication by Prof. Hugh Ryan, of University College, Dublin, of his first paper on flavone chemistry. Since that time the subject has been actively pursued in Dublin under the direction of Profs. T. J. Nolan, J. Algar and T. S. Wheeler. To mark the anniversary, University College, Dublin, is organizing a symposium on "Recent Advances in the Chemistry of Naturally Occurring Pyrones and Related Compounds", to be held during July 12-14. The title is to be widely interpreted and includes flavones, flavanones, isoflavones and coumarins. The Royal Dublin Society will consider contributions to the symposium for publication in its Proceedings. Further information can be obtained from Mrs. Eva M. Philbin, University College, Science Buildings, Upper Merrion Street, Dublin. 